\title{
Accounting
}

\section{Attraction of foreign direct investment in agriculture}

\section{Tien Do Thi Kim* ${ }^{*}$}

\begin{tabular}{|c|}
\hline C H R O N I C L E \\
\hline $\begin{array}{l}\text { Article history: } \\
\text { Received: November 20, } 2020 \\
\text { Received in revised format: } \\
\text { January } 302021 \\
\text { Accepted: March } 31,2021 \\
\text { Available online: } \\
\text { March 31, 2021 } \\
\end{array}$ \\
\hline $\begin{array}{l}\text { Keywords: } \\
\text { Foreign direct investment } \\
\text { FDI source } \\
\text { Agriculture } \\
\text { Red River Delta }\end{array}$ \\
\hline
\end{tabular}

\section{Introduction}

Vietnam is an original and long-history agricultural country $(\mathrm{Vu}, 2020)$. Currently, over $70 \%$ of the population still live-in rural areas and make a living mainly on agricultural production. Our country's agricultural production not only meets the demand for domestic food consumption but also exports to international markets, so it plays a very important role in the development of socio-economic and poverty alleviation in our country. Since Vietnam is in the stage of industrialization - modernization and deeper integration into the world economy, there are some new opportunities and challenges which require our country to build a strong commodity, modern and highly competitive agriculture (Lai \& Pham, 2020; Nguyen et al., 2020a, 2020b). All resources must be mobilized to attain these goals, of which foreign direct investment (FDI) (Hoang \& Bui, 2015) is an important resource contributing to the state development. FDI provides a significant capital source for growth, technology transfer, enhances the export capacity of agricultural products as well as creates more jobs and improves living standards for the people. However, until now there are some certain limitations of FDI attraction in agriculture, not really reaching the sector's potential. Specifically, in 2001, FDI in agriculture accounted for $8 \%$ of total FDI into Vietnam, but in 2015, this percentage was only about 1,46\% (according to reports of the Foreign Investment Department). In order to put more investment capital to agricultural development, it is remarkable that FDI in agriculture should be particularly encouraged. So, what are the real causes of this investment decline?

\footnotetext{
* Corresponding author.

E-mail address: tiendothikim089@gmail.com (T.D.T Kim) 
1408

The Red River Delta (RRD) is a large area around the lower Red River in northern Vietnam with a total area of 21.260,3 km2. The Red River Delta includes 11 provinces and cities: Hanoi, Bac Ninh, Hai Phong, Hai Duong, Ha Nam, Hung Yen, Vinh Phuc, Nam Dinh, Ninh Binh, Thai Binh and Quang Ninh, as a gate connected the East Sea to the world and also is one of the direct bridges between two dynamic development regions, Southeast Asia and Northeast Asia. The Red River Delta is one of the regions that have developed agriculture in Vietnam. In 2020, this region had the largest number of farms over the whole country with 10.268 farms, accounting for 30\% of the total farms. From 2015 to 2020, the number of farms in the Red River Delta always ranked behind the Mekong Delta region, evenly, in 2012 and 2013, only ranked third after the Mekong Delta and the Southeast region.

\section{Literature review}

\subsection{The current situation of foreign direct investment in Red River delta}

The Red River Delta is one of the two economic regions attracting the most FDI in Vietnam. In the early years of receiving FDI inflow, investment in the whole country and the Red River Delta was not significant, in 1995, FDI in the Red River Delta remained only 40 million USD. But since 2000, the amount of investment capital in the Red River Delta began to increase rapidly, more specifically, in 2000, FDI was 75.487 million USD, in 2010 it was 2,7 billion USD, reaching 7,5 billion USD in 2017, in 2019, the total FDI in the Red River Delta was 6,84 billion USD (although there was a decrease, it was still high compared to the whole country). The proportion of FDI capital in the Red River Delta over the number of whole countries has tended to increase in recent years, in 1995 this number was only 4,17\%. But in 2000, 2010, 2017, 2019; this number increased $13,4 \%, 15,5 \%, 21,1 \%, 22,8 \%$ respectively.

Up to 2019, the Red River Delta region has some provinces attracting the most investment capital, namely Hanoi with 5934 projects and an investment capital of 34,11 billion USD (ranking 3rd in the country in terms of investment capital); Bac Ninh with 1.510 projects and investment capital of 18,85 billion USD; Hai Phong (ranked 6th); Hai Phong 799 projects and investment capital of 10.7 billion USD (ranked 7th) and Hai Duong 449 projects and 8,17 billion USD (ranked 11th). In 2019, Hanoi is the city attracting the most FDI with a total registered capital of 8,45 billion USD, accounting for $22.2 \%$ of total investment capital. Investment in Hanoi is mainly capitalized by capital contribution, equity investment with 6,47 billion USD, accounting for $76,6 \%$ of the total registered investment capital of Hanoi. Along with Hanoi, Bac Ninh, Hai Phong and Ha Nam successfully attracted more than 1 billion USD of FDI in 2019.

In the period 2015-2019, in Red River Delta, a lot of big projects had been carrying out, for example: LG Display Hai Phong project in 2016, with a total registered investment capital of 1,5 billion USD by LG Display co., Ltd (Korea) in manufacturing and processing plastic OLED display for mobile devices such as mobile phones, smart watches, and tablets (this project increased additional investment capital of 500 million USD in 2018) and LG Innotek Hai Phong factory with the total registered investment capital of 550 million USD, invested by LG Innotek Co., Ltd (Korea) in manufacturing camera module in Hai Phong. In 2018, the Smart City project in Hai Boi commune, Dong Anh district, Hanoi, with a total investment capital of 4,138 billion USD, was invested by Sumitomo Corporation (Japan) aiming to build a smart urban area with a synchronous socio-infrastructure system. To produce beer and malt fermenting beer in Hanoi, Beerco Limited (Hong Kong) invested in Vietnam Beverage Limited Company 3,85 billion USD, which became the biggest FDI project in 2019.

\subsection{The current situation of FDI in terms of economic restructuring in Red River Delta}

In the period 2000 - 2018, along with the process of industrialization of the Vietnamese economy, the Red River Delta region had seen some fundamental changes in the economic structure. In 11 surveyed provinces in the Red River Delta, the process of economic restructuring came off in a positive way, but not equal among provinces and cities. According to the Department of Foreign Direct Investment - Ministry of Planning and Investment, up to December 20th 2018, FDI has been shown in all sectors, but FDI is most invested to industry area, especially the manufacturing and processing industry has a large contribution of FDI, accounting for $54 \%$ of projects and $56 \%$ of investment capital. The agriculture - forestry - fishery sector only accounts for $1.47 \%$ of the total FDI in the Red River Delta, which showed insignificant change in FDI attraction. From 2001 onwards, especially after Vietnam joined the WTO, the capital invested in service tended to increase rapidly, especially in real estate business. By the end of 2019, the number of projects in real estate business accounts for $21 \%$ of the total investment capital. In fact, the economic restructuring in the Red River Delta has an impact from investment capital, of which foreign direct investment is an important capital source. According to the data in Table 1, in the Red River Delta, the process of restructuring occurs in accordance with the trend of industrialization and modernization. The proportion of agricultural value-added to GDP has decreased significantly from 2010 to 2018. In 2018, 9 out of 11 provinces had the proportion of agriculture in GDP below $11 \%$, excluding 2 provinces Thai Binh and Nam Dinh. Thai Binh is the province having the least FDI in the Red River Delta with 74 projects and 582 million USD, no projects in agriculture. Hanoi and Bac Ninh are the two provinces with the biggest FDI in the 
I. N. M. Jodeh /Accounting 7 (2021)

region in 2018. The most obvious impact of restructuring happened in Bac Ninh, in 2010, the agricultural proportion of Bac Ninh GDP was 10,6\% and in 2018 it was 2,72\%, which shows a clear role of FDI in provincial economic restructuring.

Table 1

Economics restructuring in The Red river delta in the period of 2010- 2018*

\begin{tabular}{|c|c|c|c|c|c|c|}
\hline & & 2010 & 2014 & 2016 & 2017 & 2018 \\
\hline \multirow{3}{*}{ Hà Nội } & Agriculture & 4.9 & 3.6 & 3.2 & 2.8 & 1.94 \\
\hline & Industry & 29 & 29.6 & 29.7 & 29.7 & 22.63 \\
\hline & Services & 58.6 & 57.3 & 57.7 & 57.8 & 64.03 \\
\hline \multirow{3}{*}{ Vĩnh Phúc } & Agriculture & 13.6 & 7.81 & 7.14 & 6.51 & 6.36 \\
\hline & Industry & 57.2 & 47.6 & 44.9 & 45.6 & 47.73 \\
\hline & Services & 20.6 & 30.97 & 32.4 & 36.5 & 38.71 \\
\hline \multirow{3}{*}{ Bắc Ninh } & Agriculture & 10.6 & 4.2 & 3.6 & 2.9 & 2.72 \\
\hline & Industry & 58.4 & 77.9 & 81.6 & 83.2 & 76.55 \\
\hline & Services & 21.3 & 8.1 & 9.4 & 7.9 & 16.59 \\
\hline \multirow{3}{*}{ Quảng Ninh } & Agriculture & 5.7 & 6.5 & 6.8 & 6.3 & 5.97 \\
\hline & Industry & 52.4 & 51.2 & 51.6 & 51.3 & 49.18 \\
\hline & Services & 32 & 32.5 & 31.2 & 31.7 & 33.24 \\
\hline \multirow{3}{*}{ Hải Dương } & Agriculture & 17 & 13.2 & 12.4 & 10.6 & 10.51 \\
\hline & Industry & 43 & 47.8 & 48.3 & 50.2 & 51.38 \\
\hline & Services & 33.3 & 32.7 & 31.5 & 31.3 & 30.51 \\
\hline \multirow{3}{*}{ Hải Phòng } & Agriculture & 10.1 & 7.2 & 6.02 & 5.31 & 4.47 \\
\hline & Industry & 36.2 & 35.2 & 37.2 & 32.2 & 42.29 \\
\hline & Services & 49.3 & 50.4 & 50.4 & 49.2 & 47.25 \\
\hline \multirow{3}{*}{ Hưng Yên } & Agriculture & 20.9 & 13.8 & 12.4 & 10.9 & 10.58 \\
\hline & Industry & 42.2 & 45.8 & 46.1 & 48.6 & 51.56 \\
\hline & Services & 33.1 & 34.4 & 35.4 & 36.9 & 28.78 \\
\hline \multirow{3}{*}{ Thái Bình } & Agriculture & 34.3 & 26.7 & 28.65 & 25.82 & 24.44 \\
\hline & Industry & 32.3 & 30.8 & 29.1 & 33.14 & 36.21 \\
\hline & Services & 30.6 & 34.2 & 35.47 & 35.56 & 33.99 \\
\hline \multirow{3}{*}{ Hà Nam } & Agriculture & 21.9 & 14.3 & 12.6 & 10.6 & 9.85 \\
\hline & Industry & 43.6 & 47.7 & 49.7 & 52.7 & 56.01 \\
\hline & Services & 29.5 & 28.1 & 28.7 & 29.7 & 26.74 \\
\hline \multirow{3}{*}{ Nam Định } & Agriculture & 28.1 & 25.1 & 22.9 & 20.7 & 20.63 \\
\hline & Industry & 37.3 & 33.1 & 34.9 & 36.4 & 37.07 \\
\hline & Services & 30 & 36.1 & 38.4 & 40.2 & 38.2 \\
\hline \multirow{3}{*}{ Ninh Bình } & Agriculture & 21.6 & 14.9 & 12.2 & 11.1 & 10.29 \\
\hline & Industry & 32.5 & 36.9 & 38.3 & 37.3 & 40.73 \\
\hline & Services & 37.6 & 38.6 & 41.1 & 41.2 & 40.09 \\
\hline
\end{tabular}

* Excluding product tax from product subsidies (Source: General Statistic Office)

Up to December 31st, 2018, in parallel with FDI into industry and services, the economic structure in the Red River Delta has shifted towards increasing the value-added proportion of industry and services in GDP. The proportion of industrial value added in GDP in provinces is all over 30\%, in which some provinces have a large proportion of industrial value added in GDP such as Bac Ninh with $76,55 \%$ (total FDI into industry was 15,2 billion USD, accounting for $96,2 \%$ of provincial investment capital); Ha Nam with $56,01 \%$ (FDI into industry was 2.193 billion USD, accounting for $98,9 \%$ of the provincial investment capital); Hung Yen with 51,56\% (FDI in industry reached 3,78 billion USD, accounting for 94,97\% of provincial total investment capital); Hai Duong with 51,38\% (FDI in industry is 6,68 billion USD, accounting for $95,57 \%$ of provincial total investment capital).

Vinh Phuc and Quang Ninh also had the proportion of industrial value added in GDP of 47,43\% and 49,18\% respectively, of which FDI in industry accounted for over $88 \%$ of the total provincial investment capital. Hanoi and Hai Phong are two cities with a low proportion of industrial value added in GDP, but instead, these two cities tend to develop with high proportion of services, reaching $64,03 \%$ and $47,25 \%$ respectively. This will be the trend of future structure for cities when industrialization and modernization are completed.

As a developing country, it is difficult for Vietnam to avoid capital shortage in solving problems such as infrastructure, technology transfer, industry and cottage industry development in order to meet the requirements of the industrialization process. One of the most effective ways for Vietnam in general and the Red River Delta in particular is continuously retaining FDI attraction policies.

To see the fruits of labor, Vietnam needs to continue to strongly improve the investment environment with equality and transparency, minimization of hidden costs in applying for investment licenses, and completely elimination of corruption. It also needs to improve transport infrastructure, communication and other services to save time and costs for investors. 
Another important issue is to focus on training a skilled workforce to meet the demands of foreign investors. In addition, in order to restructure the economy towards sustainable industrialization, the Red River Delta needs to improve efficiency of using domestic investment capital, invest in urban infrastructure, ensure all conditions to promote inherent advantages of urbanization aiming to accelerate industrialization.

\section{Methodology}

\subsection{Research content}

The situation of FDI attraction into agriculture in the Red River Delta,

The reason of slow and difficult FDI attraction into agriculture of the Red River Delta,

The evaluation of FDI attraction into agriculture in the Red River Delta.

\subsection{Research samples}

According to Hair et al. (2006), if the study used Maximum Likelihood (ML) estimation method, the sample size would be determined by one of the two following ways: (i) minimum level and (ii) number of variables included in the analysis in the model.

Minimum level $=50$

The sample rate for an analytical variable $\mathrm{k}$ is $5 / 1$ or $10 / 1$.

If $\mathrm{N}<$ minimum level, the minimum will be selected. In case the model has $\mathrm{m}$ scales and $P_{j}$ is the number of jth observed variables, the minimum sample size is determined as $N=\sum_{j=1}^{m} k P_{j}$. In the study, there are 05 observed variables to measure the concept of attracting foreign direct investment and 36 observed variables to measure 7 FDI extractives factors. Thus, the minimum sample size according to Hair et al. (2006) must be: $\mathrm{N}=(05+36) \times 5=205$. Based on the minimum sample of 205 observations, 400 survey papers were given to foreign investors in agriculture in the Red River Delta to study the factors that influence the investment decision. Respondents are foreign direct investors in agriculture in the Red River Delta. A valid survey will be counted if it's fully and objectively answered, in no case a level is chosen for all questions (or 1, 2, 3, 4, 5). Valid questionnaires were entered into SPSS 22.0 software to analyze data and verify the research model.

\subsection{Methods}

Data collected from surveyed subjects were evaluated by analyzing reliability through Cronbach's Alpha coefficient, EFA analysis method, CFA analysis method and OLS regression method to test models and research hypotheses.

\subsection{Hypothesis}

Based on the above theoretical basis as well as selected appropriate factors with research reality, the research model is proposed as follows:

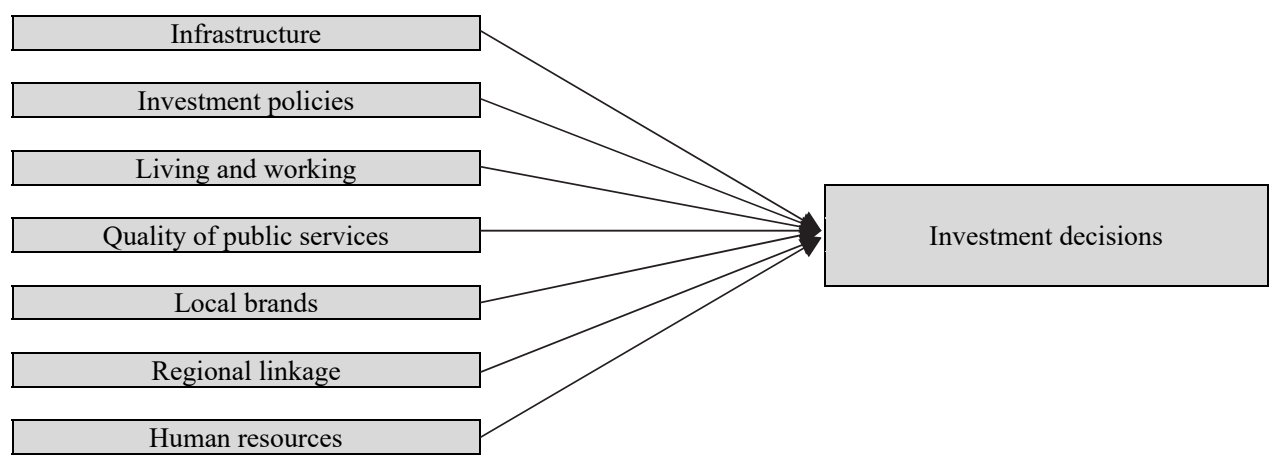

Fig. 2. Research model of factors affecting FDI attraction in agriculture in the Red River Delta 
In the process of globalization, there will be some changes in factors influencing foreign investment decisions, such as the decrease of some traditional factors such as geographic location, available resources, while high quality human resources are increasingly important. Therefore, the factors and measures of factors in the model are designed based on the selective inheritance between traditional factors and new factors updated from recent theoretical and experimental studies, especially studies in the transition economy in accordance with these research features. Since then, there are 7 factors affecting to FDI attractiveness in agriculture in the Red River Delta, including: (1) Infrastructure; (2) Investment policy; (3) Regional Linkage; (4) Human resources; (5) Living and working environment; Quality of public services; (7) Local brands. Depending on each study, the importance of each factor may differ, some of the criteria that play a decisive role in the choice of investment in one country may not be important in other countries. This issue can be explained by differences in culture, economy, society, law among countries. Based on the synthesis of previous research models, it can be seen that infrastructure is evaluated as the most influential and popular factor in most studies by investors. In fact, when investing in agriculture in the Red River Delta, the investors will make a decision based on infrastructure as the very first factor.

Investment infrastructure: this is the basic and necessary element for the production and business of any company. These factors include basic infrastructure factors such as electricity, water, transportation, land area and technical infrastructure elements such as communications, banking system.

Hypothesis H1: Infrastructure has a positive impact on the investment decisions of foreign investors in agriculture in the Red River Delta.

Investment policy: policies of the local government on investment incentives; the dynamism of government in supporting business in terms of administrative procedures, law, tax; clear, transparent documents and policies and quick deployment to enterprises so that public officials cannot take advantage of or bother enterprises.

Hypothesis H2: Investment policy has a positive impact on the investment decisions of foreign investors in agriculture in the Red River Delta region.

Regional linkage: Regional linkage to attract investment is a new task, requiring a new orientation in the assignment and cooperation between localities as well as more attention to science - technology factors of production and the choice of partners along with investment projects.

Hypothesis H3: Regional linkage has a positive impact on the investment decisions of foreign investors in agriculture in the Red River Delta.

Human resources: Abundant and cheap human resources are attractive to low-tech and labor-intensive enterprises; skillful and disciplined laborers are suitable for industrial production lines; especially managerial and technical workers with foreign language capacity are suitable for working in foreign-invested enterprises.

Hypothesis H4: Human resources have a positive impact on the investment decisions of foreign investors in agriculture in the Red River Delta.

Living and working environment: Living and working environment is reflected through factors of culture, education, health, quality of living environment, play, living, etc. The harmony and reasonable costs present a quality living environment and are suitable for investors and employees in order to effectively work for a long time.

Hypothesis H5: Living and working environment has a positive impact on the investment decisions of foreign investors in agriculture in the Red River Delta.

Quality of public services: the quality of public services is shown in solving necessary administrative procedures in investment, production and business activities as well as benefiting from the State's support in areas where the state has advantages and enterprises difficulty accessing on their own.

Hypothesis H6: The quality of public services has a positive impact on the investment decisions of foreign investors in agriculture in the Red River Delta.

Local brands: A business can be considered effective when its goals are achieved as desired. Investors often invest in locality with brands because they can save costs in understanding the investment environment and avoid risks.

Hypothesis H7: Local brands have a positive impact on the investment decisions of foreign investors in agriculture in the Red River Delta region.

Investor satisfaction: Efficiency in investment activities also shows the level of investor satisfaction. Investors who are satisfied with the locality tend to continue investing in long-term as well as recommend the locality to other investors. 


\section{Results}

\subsection{Cronbach's Alpha}

The scales in this study are evaluated by Cronbach's Alpha's reliability coefficients. Components that do not meet the reliability requirements (Cronbach's Alpha $<0.7$ for case studies or 0.6 for new studies and total variable correlation coefficients $<0.3$ ) will be rejected.

\section{Table 2}

Evaluate the scale with Cronbach's Alpha coefficients

\begin{tabular}{|c|c|c|c|}
\hline Code & Statement & $\begin{array}{l}\text { Item-total } \\
\text { correlation }\end{array}$ & $\begin{array}{l}\text { CRA if item } \\
\text { deleted }\end{array}$ \\
\hline \multicolumn{4}{|c|}{ Infrastructure: Cronbach's Alpha $=0.791$} \\
\hline CSHT1 & Investing in agriculture in The Red River Delta because of convenient transportation (time and cost). & 0.581 & 0.766 \\
\hline CSHT2 & $\begin{array}{l}\text { Investing in agriculture in The Red River Delta because this region has a power supply system that meets the requirements } \\
\text { for production and business. }\end{array}$ & 0.536 & 0.776 \\
\hline CSHT3 & $\begin{array}{l}\text { Investing in agriculture in The Red River Delta because this region has a water supply and drainage system that meet the } \\
\text { requirements for production and business. }\end{array}$ & 0.563 & 0.773 \\
\hline CSHT4 & $\begin{array}{l}\text { Investing in agriculture in The Red River Delta since this region has convenient communication systems (telephone, } \\
\text { internet, ...). }\end{array}$ & 0.599 & 0.762 \\
\hline CSHT5 & $\begin{array}{l}\text { Investing in agriculture in the Red River Delta because this region has enough land to meet the requirements for production } \\
\text { and business. }\end{array}$ & 0.529 & 0.777 \\
\hline CSHT6 & Investing in agriculture in the Red River Delta because this region has a banking system that meets the requirements. & 0.566 & 0.771 \\
\hline \multicolumn{4}{|c|}{ Investment policies: Cronbach's Alpha $=0.817$} \\
\hline CSDT1 & Investing in agriculture in The Red River Delta because this region has attractive investment incentives. & 0.594 & 0.804 \\
\hline CSDT2 & $\begin{array}{l}\text { Investing in agriculture in The Red River Delta because this region has a clear tax system (tax officers do not take } \\
\text { advantage of it for self-seeking). }\end{array}$ & 0.713 & 0.768 \\
\hline CSDT3 & $\begin{array}{l}\text { Investing in agriculture in the Red River Delta because this region has legal documents which quickly deployed to the } \\
\text { company. }\end{array}$ & 0.646 & 0.792 \\
\hline CSDT4 & Investing in agriculture in the Red River Delta because this region has dynamic leaders in supporting business & 0.61 & 0.796 \\
\hline CSDT5 & Still investing in agriculture in the Red River Delta if the locality does not have attractive policies & 0.618 & 0.796 \\
\hline \multicolumn{4}{|c|}{ Regional Linkage: Cronbach’s Alpha $=0.813$} \\
\hline LKV1 & $\begin{array}{l}\text { Investing in agriculture in the Red River Delta because there are supporting industries located in the provinces / cities in } \\
\text { the region. }\end{array}$ & 0.636 & 0.764 \\
\hline LKV2 & $\begin{array}{l}\text { Investing in agriculture in the Red River Delta region because there is a coordination among provinces / cities in trade } \\
\text { promotion. }\end{array}$ & 0.632 & 0.767 \\
\hline LKV3 & Investing in agriculture in the Red River Delta because there is a chain of goods suitable for business activities & 0.597 & 0.782 \\
\hline LKV4 & $\begin{array}{l}\text { Investing in agriculture in the Red River Delta because there is cooperation in production among the provinces in the } \\
\text { region. }\end{array}$ & 0.67 & 0.747 \\
\hline \multicolumn{4}{|c|}{ Human resources: Cronbach's Alpha $=0.805$} \\
\hline NNL1 & Investing in agriculture in the Red River Delta because there are vocational schools to meet the requirements of enterprises. & 0.528 & 0.783 \\
\hline NNL2 & Investing in agriculture in the Red River Delta because there is an abundant source of unskilled labor (labor with no skill). & 0.575 & 0.772 \\
\hline NNL3 & Investing in agriculture in the Red River Delta because there are highly disciplined workers. & 0.536 & 0.781 \\
\hline NNL4 & Investing in agriculture in the Red River Delta because the labors are able to learn and apply modern technology. & 0.559 & 0.775 \\
\hline NNL5 & Investing in agriculture in the Red River Delta because there are no language barriers for companies. & 0.528 & 0.784 \\
\hline NNL6 & Investing in agriculture in the Red River Delta because it is easy to recruit good local managers. & 0.656 & 0.753 \\
\hline \multicolumn{4}{|c|}{ Living and working environment: Cronbach's Alpha $=0.842$} \\
\hline MTSLV1 & $\begin{array}{l}\text { Investing in agriculture in the Red River Delta because disagreements between people and enterprises are satisfactorily } \\
\text { resolved. }\end{array}$ & 0.588 & 0.824 \\
\hline MTSLV2 & Investing in agriculture in the Red River Delta region because the school system here meets the demand. & 0.595 & 0.821 \\
\hline MTSLV3 & Invest in agriculture in the Red River Delta because the health system meets the needs. & 0.588 & 0.823 \\
\hline MTSLV4 & Investing in agriculture in the Red River Delta because the environment is clean and unpolluted. & 0.623 & 0.818 \\
\hline MTSLV5 & Investing in agriculture in the Red River Delta because of attractive entertainment centers & 0.641 & 0.814 \\
\hline MTSLV6 & Invest in agriculture in the Red River Delta because the people are friendly. & 0.585 & 0.823 \\
\hline MTSLV7 & Investing in agriculture in the Red River Delta because living costs are reasonable. & 0.585 & 0.823 \\
\hline \multicolumn{4}{|c|}{ Quality of Public services: Cronbach's Alpha $=0.749$} \\
\hline CLDVC1 & Investing in agriculture in the Red River Delta because the administrative procedures are simple and fast. & 0.602 & 0.64 \\
\hline CLDVC2 & Investing in agriculture in the Red River Delta because the local government carefully supports enterprises. & 0.577 & 0.694 \\
\hline CLDVC4 & $\begin{array}{l}\text { Investing in agriculture in the Red River Delta region because there are trade and investment promotion centers that } \\
\text { carefully support enterprises. }\end{array}$ & 0.587 & 0.667 \\
\hline \multicolumn{4}{|c|}{ Local brands: Cronbach’s Alpha $=0.824$} \\
\hline THDP1 & Investing in agriculture The Red River Delta because of the desire to invest in province $\mathrm{X}$ in the region. & 0.665 & 0.772 \\
\hline THDP2 & $\begin{array}{l}\text { Investing in agriculture The Red River Delta because there are many investors with successful investment in province } \mathrm{X} \\
\text { in the Red River Delta Region. }\end{array}$ & 0.645 & 0.78 \\
\hline THDP3 & $\begin{array}{l}\text { Investing in agriculture The Red River Delta because Province X in the Red River Delta possesses an impressive local } \\
\text { brand. }\end{array}$ & 0.655 & 0.777 \\
\hline THDP4 & Investing in agriculture in the Red River Delta because province $\mathrm{X}$ in the region is a promising land for investors. & 0.635 & 0.785 \\
\hline \multicolumn{4}{|c|}{ Investment Decision: Cronbach's Alpha $=0.82$} \\
\hline QDDT1 & I think the company's profit has been / will be as expected. & 0.65 & 0.775 \\
\hline QDDT2 & Investing in agriculture in the Red River Delta is a right decision. & 0.621 & 0.782 \\
\hline QDDT3 & Our company will continue to invest in long-term business in the Red River Delta. & 0.568 & 0.801 \\
\hline QDDT4 & The Red River Delta region will be introduced to other investors & 0.656 & 0.771 \\
\hline QDDT5 & Our company is very pleased with investment decision in the Red River Delta. & 0.6 & 0.792 \\
\hline
\end{tabular}


The research results show that the Cronbach's Alpha coefficients of the variables are greater than 0.7 and the total variable correlation coefficient is more than 0.3 , so these factors are acceptable and will continuously be analyzed, including: Infrastructure (0.801); Investment policies (0.827); Regional linkage (0.813); Human resources (0.805); Living and working environment (0.842); Local brands (0824); In particular, The quality of public services has Cronbach's Alpha coefficient of 0.716; however, the value of the Cronbach's Alpha column will be 0.749 if the variable CLDVC3 is deleted, this coefficient is greater than the Cronbach Alpha coefficient so the observed variable CLDVC3 should be removed to increase the scale reliability.

The results of testing the scale of investment determinants of FDI enterprises in the Red River Delta shows that Cronbach's Alpha coefficient is 0.82 and the total variable correlation is greater than 0.3 , so the satisfaction factor ensures the reliability of the scale that is continuously used.

\subsection{Exploratory Factor Analysis (EFA)}

When performing factor analysis, the Extraction Method as Principal components with the Varimax rotation will be used. After testing the reliability of the scale, 35 observed variables of the 7 component scales are conducted to the exploratory factor analysis (EFA). The results of the exploratory factor analysis (EFA) show that the coefficient KMO $=0.775$ which means the data is suitable for factor analysis $(0.5<\mathrm{KMO}<1)$ and the coefficient of Eigenvalue $=1.959$, which is greater than 1 , the total variance extracted is $58.369 \%$, greater than $50 \%$ so the test coefficients are satisfactory.

\section{Table 4}

Analysis of EFA with determinants of agricultural investment in Red River Delta region

\begin{tabular}{|c|c|c|c|c|c|}
\hline Variable & Factor loading & Variable & Factor loading & Variable & Factor loading \\
\hline QDDT4 & 0.796 & QDDT5 & 0.749 & Cumulative of variance & 58.827 \\
\hline QDDT1 & 0.793 & QDDT3 & 0.725 & KMO & 0.848 \\
\hline QDDT2 & 0.770 & Eigenvalue & 2.941 & Bartlett's test & Sig $=0.000$ \\
\hline
\end{tabular}

From the results of the Exploratory Factor Analysis (EFA), the KMO coefficient $=0.848$ which means the data is suitable to conducted to factor analysis $(0.5<\mathrm{KMO}<1)$ and Eigenvalue coefficient $=2,941$, greater than 1 , Total variance extracted is $58.8 \%$, greater than $50 \%$ so the test coefficients are satisfactory. Considering the factor rotation matrix: the observed variables have factor loading coefficients greater than 0.5 , so the observed variables are eligible to be analyzed in the next steps. Thus, compared to the theoretical model, after analyzing the exploratory factors EFA, the observed variables converge into groups of factors like the original model, so the survey results are completely reliable to be included in linear regression analysis.

\subsection{Pearson correlation matrix}

An analysis of Pearson's correlation coefficient matrix is taken among the independent variables and between the independent variables and the dependent variables, the results show that:

The sig. values of the variables CSHT, THDP, LKV, MTSLV are greater than 0,05 , showing that these variables have no correlation with each other. However, the correlation coefficient of CSDT with HR, CLD is less than 0,05, but the correlation coefficient is quite small, so it is likely that the independent variables do not correlate with each other, that is, there will be no multicollinearity phenomenon.

All sig. values of the independent variables to the dependent variables are less than 0,05 , so it can be seen that these independent variables are correlated with the dependent variable. Particularly, the fact that the CSDT variable with sig value greater than 0,05 is not enough to conclude that there is a relationship between this independent variable and the dependent variable, it is necessary to have the results of multiple linear regression analysis to confirm.

Research model:

$Q D D T=\beta_{0}+\beta_{1} C S H T+\beta_{2} C S D T+\beta_{3} L K V+\beta_{4} N N L+\beta_{5} C L D V C+\beta_{6} M T S L V+\beta_{7} T H D P+\varepsilon$

Of which: QDDT: Investment decisions of foreign investors in the Red River Delta region; CSHT: infrastructure, CSDT: Investment policy mechanism; LKV: Regional linkage; NNL: Human resources; CLDVC: Quality of public services; MTSLV: Living and working environment; THDP: Local brands.

\section{Linear regression analysis}

Testing the linear regression model by performing at the same time (Enter method), of which the variables are taken at the same time in the analysis to produce the final results. 


\section{Suitability of the model}

The results of summarizing the regression model with the Enter command show that adjusted R2 (Adjusted R square) $=0.594$, so the research model is suitable with the research data at 59.4\%. We can see that adjusted R2 (0.594) is smaller than R2 (0.601), so it is safer to use it to evaluate the suitability of the research model, because it does not exaggerate the suitability of the model.

\section{Table 5}

Assessment Results of model Suitability

\begin{tabular}{llllll}
\hline Model & $\mathrm{R}$ & $\mathrm{R}^{2}$ & Adjusted $\mathrm{R}^{2}$ & Std. Error of the Estimate & Durbin-Watson \\
\hline 1 & $.775^{\mathrm{a}}$ & .801 & .594 & .28467 & 2.014 \\
\hline a Predictors: (Constant) CSDT CSHT, THDP, & MTSLV, LKV, CLDVC, NNL & &
\end{tabular}

a. Predictors: (Constant), CSDT, CSHT, THDP, MTSLV, LKV, CLDVC, NNL

b. Dependent Variable: QDDT

ANOVA analysis results show significance level $<0.05$, so it can be concluded that the research model is suitable.

Table 6

ANOVA test results

\begin{tabular}{lllllll}
\hline Model & & Sum of Squares & df & Mean Square & F & Sig. \\
\hline \multirow{2}{*}{1} & Regression & 45.315 & 7 & 6.474 & 82.887 & $.000 \mathrm{~b}$ \\
& Residual & 30.064 & 371 & .081 & & \\
\cline { 2 - 6 } & Total & 75.379 & 378 & & \\
\hline
\end{tabular}

a. Dependent Variable: QDDT

b. Predictors: (Constant), CSDT, CSHT, THDP, MTSLV, LKV, CLDVC, NNL

ANOVA analysis results show that the statistic value $\mathrm{F}=82,887$ is calculated from the R-Square value of the full model, the sig value. $=0.000$ shows that it is safe to reject the hypothesis $\mathrm{H}_{0}$ : a set of independent variables that are not related to the dependent variable (except for the constant), which means the model is suitable with the whole market data. The estimated linear regression equation shows that the independent factors have a directly proportional impact on customer decisions (increasing). The factors are statistically significant and highly reliable (sig. $=<0.05$ ), the NV factor in particular is not statistically significant due to the sig value. greater than 0.05 .

Table 7

The results of the regression model

\begin{tabular}{|c|c|c|c|c|c|c|}
\hline & \multicolumn{2}{|c|}{ Unstandardized coefficient } & Standardized & T value & Significance & Multicollinearity (VIF) \\
\hline & B & Error & Beta & & level & \\
\hline Constant & -1.98 & 0.261 & & -7.594 & 0.00 & \\
\hline CSHT & 0.413 & 0.03 & 0.454 & 13.757 & 0.00 & 1.015 \\
\hline MTSLV & 0.104 & 0.03 & 0.116 & 3.519 & 0.00 & 1.016 \\
\hline CLDVC & 0.249 & 0.032 & 0.261 & 7.821 & 0.00 & 1.034 \\
\hline THDP & 0.168 & 0.026 & 0.21 & 6.346 & 0.00 & 1.022 \\
\hline NNL & 0.399 & 0.032 & 0.423 & 12.61 & 0.00 & 1.045 \\
\hline LKV & 0.131 & 0.026 & 0.165 & 4.963 & 0.00 & 1.028 \\
\hline CSDT & 0.147 & 0.028 & 0.177 & 5.208 & 0.00 & 1.071 \\
\hline
\end{tabular}

Firstly, the measurement hypotheses $\mathrm{H} 1, \mathrm{H} 2, \mathrm{H} 3, \mathrm{H} 4, \mathrm{H} 5, \mathrm{H} 6, \mathrm{H} 7$ proposed in the original theoretical model are approved due to sig value $<0.05$. The testing results show that 7 groups of factors are accepted at the significance level of $5 \%$, reliability level of $95 \%$. Investment decisions of foreign investors are influenced by 07 factors according to the following impact levels: (1) Infrastructure; (2) Human resources; (3) Quality of public services; (4) Local brands; (5) Investment policy mechanism; (6) Regional linkage; (7) Living and working environment.

At the same time, the regression model on the investment decision of foreign investors in the Red River Delta after standardization is presented as: $\mathrm{QDDT}=-1.98+0.413 \times \mathrm{CSHT}+0.147 \times \mathrm{CSDT}+0.104 \times \mathrm{MTSLV}+0.249 \times \mathrm{CLDVC}+0.168$ $\times \mathrm{THDP}+0.399 \times \mathrm{NNL}+0.131 \times \mathrm{LKV}+\varepsilon$

Secondly, the influence level (importance) of foreign investors' decisions on investment in the Red River Delta is determined as follows:

Infrastructure: The most influential factor on foreign investors' decisions. Specifically, when the influence level of investment increases / decreases by 1 unit, the decision of foreign investors will increase / decrease by 0.413 units. 
Human resources: The second most influential factors in foreign investors' decisions. Specifically, when the factor of human resources increases / decreases by 1 unit, the investor's decision will increase / decrease by 0.399 units.

Quality of public services: The third most influential factors in the decision of foreign investors. Specifically, when the factor of the quality of public services increases / decreases by 1 unit, the investor's decision will increase / decrease by 0.249 units.

Local brands: The fourth most influential factor in the decision of foreign investors. Specifically, when the factor of local brands increases / decreases by 1 unit, the investor's decision will increase / decrease by 0.168 units.

Investment policy mechanism: is the fifth most influential factor in the decisions of foreign investors. Specifically, when the factor of the investment policy mechanism increases / decreases by 1 unit, the investor's decision will increase / decrease by 0.147 units.

Regional linkage: is the sixth most influential factor in the decision of foreign investors. Specifically, when the factor of regional linkage increases / decreases by 1 unit, the investor's decision will increase / decrease by 0.131 units.

Living and working environment: is the factor that has impact on decisions of foreign investors. Specifically, when the factor of living and working environment increases / decreases by 1 unit, the investor's decision will increase / decrease by 0.104 units.

\section{Recommendation}

The main factors influencing foreign investors' decisions to invest in agriculture in the Red River Delta should be studied to propose recommendations for policies and solutions to foreign investment attraction.

In practical terms, through all research results, it is highly agreed that investment decisions of foreign investors in agriculture in the Red River Delta are affected by factors in order from high to low: (1) Infrastructure; (2) Human resources; (3) Quality of public service; (4) Local brands; (5) Investment policy mechanism; (6) Regional linkage; (7) Living and working environment.

Firstly, it must be mentioned that the impact of infrastructure on the investment decisions of foreign investors is completely reasonable in the case the study is in agriculture in the River Delta. Infrastructure is a basic and essential element for the production and business of any company. This element is included in electricity, water, transportation, land area and technical infrastructure elements such as communication, banking system. So infrastructure has a positive impact on investors' satisfaction.

Secondly, the factor of human resources is an important factor that an enterprise must consider when deciding whether to invest in the locality or not. Abundant and cheap human resources attract low-tech and labor-intensive enterprises; skillful and disciplined labor are suitable for industrial production lines; and especially manager and technical workers with foreign language capacity working in foreign-invested enterprises. A locality with abundant and diversified human resources is always an attractive factor to invest, so the influence of this factor on the decision to invest in agriculture in the Red River Delta is completely reasonable.

Local brand: A business can be considered effective when its goals are achieved as desired. Investors often invest in locality with brands because they can save costs in understanding the investment environment and avoid risks.

Investment policies: policies of the local government on investment incentives; the dynamism of government in supporting business in terms of administrative procedures, law, tax; clear and transparent documents and policies and quick deployment to enterprises so that public officials cannot take advantage of or bother enterprises.

Regional linkage: Regional linkage to attract investment in accordance with economic restructuring and growth model transformation is a new task, requiring a new orientation in the assignment and cooperation between localities as well as more attention to science - technology factors of production and the choice of partners along with investment projects.

Living and working environment is reflected through factors of culture, education, health, quality of living environment, play, living,.. The harmony and reasonable costs present a quality living environment and suitable for investors and employees in order to effectively work in long time.

From research results, the new factor "regional linkage" is importantly affecting FDI attraction to the economic region. Regional linkage is presented in economy, politics and socio. In order to effectively deploy regional linkage, the connection of transport infrastructure systems and regional urban development are the two most important issues for the development of the Southern key economic region in general and for agriculture in the Red River Delta in particular. 


\section{Conclusion}

The Red River Delta is a region with many favorable conditions for the development of agricultural production in order to become a spearhead economic sector with many competitive advantages compared to other economic regions. However, in fact investment in the agriculture compared to other sectors is limited, even the investment trend is unstable and there is a decline in some capital flows. While the state budget capital, credit capital ... tend to increase, FDI capital has almost no growth, even decline and remain unstable. While FDI inflows in the world are increasing in the agriculture and economic integration becomes deeper and broader, FDI in Vietnamese agriculture in general and the Red River Delta in particular go against the trend. Therefore, it is necessary to focus on studying factors affecting the FDI attraction in agriculture of the Red River Delta in the context of attracting FDI into the region and agriculture of the country.

\section{References}

Hoang, H., \& Bui, D. (2015). Determinants of foreign direct investment in ASEAN: A panel approach. Management Science Letters, 5(2), 213-222.

Lai, T., \& Pham, D. (2020). The quality of audit services: An assessment from FDI clients in Vietnam. Accounting, 6(6), 1071-1076.

Nguyen, H., Tham, J., Khatibi, A., \& Azam, S. (2020a). Conceptualizing the effects of transfer pricing law on transfer pricing decision making of FDI enterprises in Vietnam. International Journal of Data and Network Science, 4(2), 187-198.

Nguyen, H., Tham, J., Khatibi, A., \& Azam, S. (2020b). Conceptualizing the effects of corporate tax rate differentials on transfer pricing activities of FDI enterprises in Vietnam. Accounting, 6(3), 291-300.

$\mathrm{Vu}, \mathrm{T}$. (2020). The effect of political factors on FDI attraction in Vietnam. Accounting, 6(6), 1077-1082.

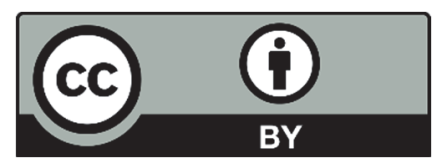

C 2021 by the authors; licensee Growing Science, Canada. This is an open access article distributed under the terms and conditions of the Creative Commons Attribution (CC-BY) license (http://creativecommons.org/licenses/by/4.0/). 